\title{
AWARENESS AND KNOWLEDGE OF ORAL CANCER IN THE CITY OF BAGHDAD, IRAQ: A QUESTIONNAIRE-BASED SURVEY
}

\author{
Muhanad L. Alshamii ${ }^{1}$, Hayder R. Abdulbaqi ${ }^{2}$, Ali A. Abdulkareem ${ }^{2}$ \\ 'Department of Dentistry, Dijlah University College, Baghdad, Iraq \\ 2Department of Periodontics, College of Dentistry/University of Baghdad, Iraq
}

\begin{abstract}
INTRODUCTION: Early detection and successful management of oral cancer (OC) is highly dependent on the early detection of this malignancy, which is related to individuals' awareness and knowledge about this fatal condition. Овјестіves: This pilot study was designed to estimate awareness degree of Iraqi patients about OC.

MATERIAL AND METHODS: A total of 1,024 questionnaires were mailed to six randomly selected governmental specialized dental centers in the city of Baghdad. The questionnaire consisted of basic information section including age, gender, alcohol drinking, smoking, and frequency of dental visits. The other section comprised seven questions to estimate the degree of OC awareness.

RESULTS: A total of 318 participants (60\% females, $40 \%$ males) responded to the questionnaire. The mean response of the sample was $0.36 \pm 0.201$, and the majority of participants answered only 2-3 questions correctly and no one responded to all seven questions correctly. The association of awareness to different factors showed that the only significant finding was related to information given by a dentist to the patient (OR: 2.9; 95\% CI) about OC.

Conclusions: In general, the degree of awareness of Iraqi patients was low about OC. The knowledge about OC considerably increased when the subjects received information from their dentists.
\end{abstract}

KEY WORDS: awareness, oral cancer, knowledge.

J Stoma 2019; 72, 6: 263-268

DOI: https://doi.org/10.5114/jos.2019.93796

\section{INTRODUCTION}

Oral cancer (OC) is ranked among top ten most prevalent cancers in the world, and accounts for $2.1 \%$ of all cancers. Every year, almost 275,000 new OC patients are diagnosed and at least 120,000 die from this disease $[1,2]$. More than $90 \%$ of OC cases are oral squamous cell carcinoma (OSCC) affecting the lips, tongue, pharynx, and other sites of the oral cavity [3]. OC is multifactorial in nature, which could be triggered by range of risk factors including drugs, smoking, exposure to sunlight, viruses such as human papilloma virus, occupational hazard, and diet [4]. The prevalence of OC in Iraq was not sufficiently highlighted, and the only available study from 2000-2008 showed that OC was accounted for $2 \%$ of all reported cancers, with no clear identification of risk factors or mortality rate of OC [5].

Globally, several epidemiological studies have reported that the prevalence of OC is increased with aging [6]. The majority of Iraqis with OC, from both genders, were aged 60 and above, and the incidence of OC

\section{JOURNAL OF} STOMATOLOGY 
among males is higher than among females [5, 7]. At advance stages of OSCC, the clinical picture probably indicates suspicious malignancy, but misdiagnosis is expected at earlier stages [8]. Clinical appearance of OSCC is variable, which could be presented as leukoplakia or erythroplakia, persistent ulcer, or as an exophytic mass, which had already become malignant [9]. Indeed, early detection of oral malignancies, supported with prognostic markers to evaluate the prognosis, considerably aids in the determination of appropriate treatment, thereby increasing the long-term survival of patients with potential risk of recurrence. Interestingly, results from many surveys worldwide indicate that the majority of populations were not able to distinguish persistent ulcer or red patches as the early signs and symptoms of OSCC [10]. For instance, at least $60 \%$ of OC cases in Ireland received the treatment at late stages associated with deficiency in awareness of this malignant condition. Further, another study conducted in the UK suggested lack of knowledge about risk factors, signs, and symptoms among individuals with OC risk. Unfortunately, small and asymptomatic lesions that can be effectively treated are missed, which highlights the vital role of a dentist in early diagnosis of OC $[11,12]$. Literatures suggest considerable lack of public awareness about OC, which seriously impede early diagnosis [13].

\section{OBJECTIVES}

The knowledge concerning OC is essential for an individual's OC awareness, which potentially minimize the mortality and morbidity by early detection. For that reason, the objective of this study was to determine the level of OC awareness and knowledge in association with variable factors in Baghdad, Iraq.

\section{MATERIAL AND METHODS}

\section{STUDY DESIGN}

This study is a questionnaire-based survey, which was conducted from March 2019 to May 2019, to evaluate the awareness degree of the Iraqi population in Baghdad, Iraq. The targeted sample was the patients attending governmental specialized dental centers (GSD) who were seeking dental treatment. Six GSD were randomly selected for this study, three in Al-Karkh district and three in Al-Rasafa district on the western and eastern sides of the river Tigris, respectively. A total of 175 copies of questionnaires, translated to Arabic, were mailed to each GSD, and then randomly delivered to patients who accepted to voluntarily answer the questionnaires' questions. Any patient who was over 18 -years-old, and could read and understand the questions included in the questionnaire was invited to participate in this survey.

\section{SAMPLE SIZE}

The targeted population were patients who were waiting in the GSD for over one week, five working days, which makes 50 patients daily; thereby, the total number was 250 patients. The total sample for all GSD per week was equal to 1,500 patients.

Sample size was estimated according to the following formulas:

Sample size $=($ Distribution of $50 \%) /(($ Margin of error\%/Confidence level score $)^{2}$ ).

Confidence level = 1.96 (for confidence level of 95\%), margin of error $=0.05$.

True sample $=($ Sample size $\mathrm{x}$ population $) /($ Sample size + population -1$)$.

The calculated sample size for the current survey was equal to 306 participants. The total sample size for this study was estimated as 1,024 (multiplying the calculated sample size by 4 ) to avoid any reduction of respondents.

\section{QUESTIONNAIRE}

The questionnaire used in this study was adapted from previous survey [14] with several modifications. The questionnaire's questions were categorized into basic information and awareness sections (Table 1). Every respondent was asked to tick only one answer for each question. Any question having two ticked answers or more was not considered. The responses to questions, which had multiple-choice answers in the awareness section were further coded, as shown in Table 2 . In the awareness section, the response for each question was given 0 when the response was wrong and 1 for each correct response. The awareness degree and mean of awareness for each respondent was calculated by summation of correct responses over the total number of questions. The respondent was considered aware when the mean of awareness was $\geq 0.5$ (range, $0-1$ ).

\section{STATISTICAL ANALYSIS}

The statistical analysis was carried out using SPSS software (IBM Corp., IBM SPSS Statistics for Windows, version 23.0). The responses were represented as percentage and frequency, while awareness degree was represented as mean and standard deviation. $\chi^{2}$ and independent sample $t$ tests were used for comparisons between groups with categorical and measurable data, respectively. The significant differences between groups were accepted with $p$ value $<0.05$.

\section{RESULTS}

The percent of respondents was equal to $31.1 \%$ (318 out of 1,050$)$, which was considered satisfactory based on the calculated sample size (306). The sample consist- 
ed of $190(59.7 \%)$ females and 128 (40.3\%) males, with an average age of $34.72 \pm 12.47$ and age range $18-80$ years.

The mean awareness of the study sample was $0.36 \pm$ 0.201 (range, 0-0.86). Analysis of the responses to questions about OC awareness showed that the participants' believed susceptibility to OC increased in individuals aging more than 40 years and males more affected than females. Also, the majority of participants indicated that $\mathrm{OC}$ is not an infectious condition. However, the most of responses were significantly higher for "incorrect" in comparison to "correct" answer about questions regarding causes, oral manifestation, diagnosis, and treatment of OC (Table 2).

Frequency of correct answers (out of 7 questions) of the participants were relatively low, in which majority of them (172, about 54\%) answered only 2-3 questions correctly. No one answered all questions and only $8(2.5 \%)$ participants answered 6 out of 7 questions, while 29 (9.1\%) did not answer any question (Table 3 ). The awareness of participants according to different demographic variables included in this survey did not show any significant differences except for those being informed by a dentist about OC (Table 4). Further analysis showed that the awareness about OC was significantly associated with knowledge acquired from a dentist (odd ratio, 2.95 at $95 \%$ confidence interval) (Table 5).

\section{DISCUSSION}

OC is a life-threatening condition affecting considerable proportion of population worldwide with high mortality rate at advanced stages [2]. Public awareness about this malignancy has been reported to be low in many international studies. The main problem associated with OC is the difficulty in recognizing early alarming signs, which are mostly confused with other non-malignant oral pathologies by both patients and dentists in other occasions. In Iraq, available studies did not provide full description about incidence and prevalence of OC, with serious lack in the overall knowledge of the public about OC. Thus, this questionnaire was designed to assess the level of knowledge and awareness of Iraqi individuals inhabiting city of Baghdad.

$\mathrm{OC}$ is a multifactorial malignancy, in which initiation and progression of this condition is highly determined by range of risk factors such as age, gender, exposure to carcinogenic factor(s), and genetics. Analysis of responses showed that most of the answers indicated males as more prone to OC than females. Many studies have reported higher association of male with OC; a systematic review based on nineteen surveys from thirteen countries around the world supported increased male predisposition to OC [15]. Furthermore, another study on incidence of OC in the oro-pharyngeal region in the United States from 1975-1998, reported OSCC male : female ratio of $3: 1$ [16]. Answers related to age association with increased incidence of OC were mostly correct. This is

\section{TABLE 1. Sections of the questionnaire}

\begin{tabular}{|c|c|}
\hline \multicolumn{2}{|l|}{ A. Basic information } \\
\hline Questions & Answers \\
\hline How old are you? & ................ \\
\hline \multirow{2}{*}{ What is your gender? } & Female \\
\hline & Male \\
\hline \multirow{2}{*}{ Are you alcoholic? } & No \\
\hline & Yes \\
\hline \multirow{2}{*}{ Do you smoke? } & No \\
\hline & Yes \\
\hline \multirow{2}{*}{ Did your dentist inform you about oral cancer? } & No \\
\hline & Yes \\
\hline \multirow{2}{*}{ Do you frequently visit your dentist? } & No \\
\hline & Yes \\
\hline \multicolumn{2}{|l|}{ B. Cancer awareness section } \\
\hline Questions & Correct responses \\
\hline $\begin{array}{l}\text { According to age, who are more susceptible to } \\
\text { oral cancer? } \\
\qquad 40 \text { years } \\
\quad \geq 40 \text { years }\end{array}$ & $<40$ years \\
\hline $\begin{array}{l}\text { According to gender, who have the higher } \\
\text { incidence? } \\
\quad \text { Females } \\
\text { Males }\end{array}$ & Males \\
\hline $\begin{array}{l}\text { Potential risk factors of oral cancer? } \\
\text { Smoking } \\
\text { Alcohol } \\
\text { Genetic factor } \\
\text { Neglected oral hygiene } \\
\text { Work pollution } \\
\text { Immunity disturbance } \\
\text { Viral infection } \\
\text { All the above }\end{array}$ & All the above \\
\hline $\begin{array}{l}\text { Potential oral manifestation of oral cancer? } \\
\text { Oral ulceration } \\
\text { White or red spots in oral cavity } \\
\text { Swelling in oral cavity } \\
\text { All the above }\end{array}$ & All the above \\
\hline $\begin{array}{l}\text { Is oral cancer a contagious disease? } \\
\text { Yes } \\
\text { No }\end{array}$ & No \\
\hline $\begin{array}{l}\text { How can oral cancer be diagnosed? } \\
\text { X-ray } \\
\text { Biopsy and histopathology } \\
\text { CT scan } \\
\text { MRI } \\
\text { Clinical examination of oral cavity } \\
\text { All the above }\end{array}$ & All the above \\
\hline $\begin{array}{l}\text { How can oral cancer be treated? } \\
\text { Surgical intervention } \\
\text { Chemotherapy } \\
\text { Radiation } \\
\text { All the above }\end{array}$ & All the above \\
\hline
\end{tabular}


TABLE 2. Awareness section responses

\begin{tabular}{|c|c|c|c|c|c|c|}
\hline Question & & $\begin{array}{c}\text { Frequency, } \\
n(\%)\end{array}$ & $p$ value* & $\begin{array}{c}\text { Total } \\
\text { respondents }\end{array}$ & $\begin{array}{l}\text { Total non- } \\
\text { respondents }\end{array}$ & Total sample \\
\hline \multirow{2}{*}{$\begin{array}{l}\text { According to age, who are more } \\
\text { susceptible to oral cancer? }\end{array}$} & Incorrect & $100(31.4)$ & \multirow{2}{*}{0.000} & \multirow{2}{*}{$283(89 \%)$} & \multirow{2}{*}{$35(11 \%)$} & \multirow{14}{*}{ 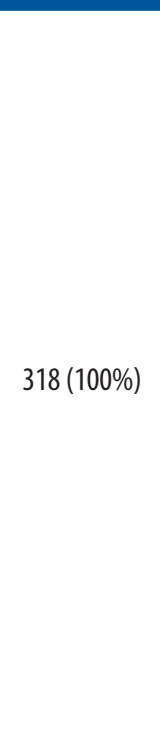 } \\
\hline & Correct & $183(57.5)$ & & & & \\
\hline \multirow{2}{*}{$\begin{array}{l}\text { According gender, who have } \\
\text { the higher incidence? }\end{array}$} & Incorrect & $60(18.9)$ & \multirow{2}{*}{0.000} & \multirow{2}{*}{$287(90.3 \%)$} & \multirow{2}{*}{$31(9.7 \%)$} & \\
\hline & Correct & 227 (71.4) & & & & \\
\hline \multirow{2}{*}{$\begin{array}{l}\text { What are the potential risk } \\
\text { factors of oral cancer? }\end{array}$} & Incorrect & $175(55.0)$ & \multirow{2}{*}{0.000} & \multirow{2}{*}{$251(78.9 \%)$} & \multirow{2}{*}{$67(21.1 \%)$} & \\
\hline & Correct & $76(23.9)$ & & & & \\
\hline \multirow{2}{*}{$\begin{array}{l}\text { Potential oral manifestation } \\
\text { of oral cancer? }\end{array}$} & Incorrect & $172(54.1)$ & \multirow{2}{*}{0.000} & \multirow{2}{*}{$178(56 \%)$} & \multirow{2}{*}{$140(44 \%)$} & \\
\hline & Correct & $6(1.9)$ & & & & \\
\hline \multirow{2}{*}{$\begin{array}{l}\text { Is oral cancer a contiguous } \\
\text { disease? }\end{array}$} & Incorrect & $73(23.0)$ & \multirow{2}{*}{0.000} & \multirow{2}{*}{$290(91.2 \%)$} & \multirow{2}{*}{$28(8.8 \%)$} & \\
\hline & Correct & $217(68.2)$ & & & & \\
\hline \multirow{2}{*}{$\begin{array}{l}\text { How can oral cancer be } \\
\text { diagnosed? }\end{array}$} & Incorrect & $217(68.2)$ & \multirow{2}{*}{0.000} & \multirow{2}{*}{$226(71.1)$} & \multirow{2}{*}{$92(28.9 \%)$} & \\
\hline & Correct & $9(2.8)$ & & & & \\
\hline \multirow{2}{*}{ How can oral cancer be treated? } & Incorrect & $124(39.0)$ & \multirow{2}{*}{0.004} & \multirow{2}{*}{$207(65.1 \%)$} & \multirow{2}{*}{$111(34.9 \%)$} & \\
\hline & Correct & $83(26.1)$ & & & & \\
\hline
\end{tabular}

TABLE 3. Distribution of correct answers among the study sample

\begin{tabular}{|c|c|c|}
\hline $\begin{array}{l}\text { Correct answers } \\
\text { of } 7 \text { questions }\end{array}$ & Frequency & $\%$ \\
\hline 0 & 29 & 9.1 \\
\hline 1 & 42 & 13.2 \\
\hline 2 & 87 & 27.4 \\
\hline 3 & 85 & 26.7 \\
\hline 4 & 53 & 16.7 \\
\hline 5 & 14 & 4.4 \\
\hline 6 & 8 & 2.5 \\
\hline 7 & 0 & 0 \\
\hline Total & 318 & 100 \\
\hline
\end{tabular}

in agreement with several reports suggesting aging ( $>40$ years) as a risk factor for OC [7, 17-19]. Another question that was answered correctly was whether cancer is contiguous or not, which agreed with results from other study conducted in India [20]. It is well-accepted that OC cannot be transmitted as other infectious diseases due to the multifactorial nature of this condition $[21,22]$. Results from a study about Tasmanian devil showed that devil facial tumor disease (DFTD) was transmitted between the animals by biting the facial region [23]. However, this could be species-related disease as there is no strong evidence about transmission of oral cancer in human or other animals. Other questions were mostly not answered correctly regarding knowledge about manifestation, diagnosis, treatment approach, and potential risk factors of OC. This agrees with Amarasinghe et al. [24] who showed that the majority of participants in their study were not aware about signs and symptoms of OC. Additionally, another study reported that the analyzed population were not familiar with the most common risk factors of oral malignancy [25]. Moreover, the deficiency in knowledge about the diagnosis and treatment methods of OC was presented in a study carried out by Singh et al. in rural areas of Chandigarh, India [20].

The effect of different demographic and socioeconomic variables on the rate of the correct response was also investigated in previous studies. The degree of awareness to OC according to gender in previous questionnaire-based surveys showed no significant differences between males and females [26, 27], which is consistent with the results of our study. Similarly, the same consistency was observed between responses of the current survey with other studies in relation to age $[26,27]$, i.e. awareness was not associated with age. Nevertheless, our results disagree with survey conducted in the UAE, which showed significant differences in relation to gender and younger adults [25]. This could be attributed to variations in sampling methods or differences in educational level among generations of that community. Interestingly, the patients at risk of potentially developing OC, smokers and alcoholics in particular, did not show any significant difference in the level of awareness with non-smoker and non-alcoholic individuals. These results are considered significant, especially when it is known that more than $50 \%$ of OC patients in Iraq are smokers [28]. Unfortunately, no data about alcoholism is available in Iraq as this habit is socially unacceptable, which hinders a proper reporting on this habit by pa- 
TABLE 4. Awareness of the study sample grouped according to different factors

\begin{tabular}{|c|c|c|c|c|c|c|c|c|}
\hline \multirow[t]{2}{*}{ Question } & \multirow[t]{2}{*}{$n$} & \multirow[t]{2}{*}{ Mean } & \multirow[t]{2}{*}{ SD } & \multirow{2}{*}{$\begin{array}{c}\text { Mean } \\
\text { difference }\end{array}$} & \multirow[t]{2}{*}{ SE difference } & \multirow[t]{2}{*}{$p$ value* } & \multicolumn{2}{|c|}{$\begin{array}{l}95 \% \text { confidence interval } \\
\text { of the difference }\end{array}$} \\
\hline & & & & & & & Lower & Upper \\
\hline \multicolumn{9}{|l|}{ Do you smoke? } \\
\hline No & 227 & 0.365 & 0.197 & \multirow{2}{*}{0.01493} & \multirow{2}{*}{0.025} & \multirow{2}{*}{0.551} & \multirow{2}{*}{-0.0342} & \multirow{2}{*}{0.0641} \\
\hline Yes & 91 & 0.350 & 0.211 & & & & & \\
\hline \multicolumn{9}{|l|}{ Gender } \\
\hline Female & 190 & 0.362 & 0.190 & \multirow{2}{*}{0.00415} & \multirow{2}{*}{0.023} & \multirow{2}{*}{0.857} & \multirow{2}{*}{-0.0412} & \multirow{2}{*}{0.0495} \\
\hline Male & 128 & 0.358 & 0.216 & & & & & \\
\hline \multicolumn{9}{|c|}{ Are you alcoholic? } \\
\hline No & 283 & 0.361 & 0.195 & \multirow{2}{*}{0.00633} & \multirow{2}{*}{0.036} & \multirow{2}{*}{0.861} & \multirow{2}{*}{-0.0647} & \multirow{2}{*}{0.0774} \\
\hline Yes & 35 & 0.355 & 0.243 & & & & & \\
\hline \multicolumn{9}{|c|}{ Do you frequently visit your dentist? } \\
\hline No & 194 & 0.346 & 0.207 & \multirow{2}{*}{-0.03754} & \multirow{2}{*}{0.023} & \multirow{2}{*}{0.105} & \multirow{2}{*}{-0.0829} & \multirow{2}{*}{0.0078} \\
\hline Yes & 124 & 0.383 & 0.189 & & & & & \\
\hline \multicolumn{9}{|c|}{ Did your dentist inform you about oral cancer? } \\
\hline No & 253 & 0.338 & 0.185 & \multirow{2}{*}{-0.10736} & \multirow{2}{*}{0.027} & ח & ב 0161 & 00525 \\
\hline Yes & 65 & 0.446 & 0.234 & & & 0.000 & 0.1012 & J \\
\hline Age & & & & & & & & \\
\hline$<34$ years & 157 & 0.373 & 0.202 & 002184 & ברח0 & 0.336 & 7בר 00 & 00664 \\
\hline$\geq 34$ years & 157 & 0.351 & 0.199 & 0.02104 & $0.0 \angle 2$ & 0.550 & $-0.0<21$ & 0.0004 \\
\hline
\end{tabular}

TABLE 5. Association between awareness and knowledge acquired from dentists

\begin{tabular}{|c|c|c|c|c|}
\hline \multirow{2}{*}{ Question } & & \multicolumn{2}{|c|}{ Awareness* } & \multirow[t]{2}{*}{ Total } \\
\hline & & No, $n(\%)$ & Yes, $\boldsymbol{n}(\%)$ & \\
\hline \multirow{2}{*}{ Did your dentist inform you about oral cancer? } & $\mathrm{No}^{* *}$ & $204(80.6)$ & $49(19.4)$ & $253(100.0)$ \\
\hline & Yes & $38(58.5)$ & $27(41.5)$ & $65(100.0)$ \\
\hline Total & & $242(76.1)$ & $76(23.9)$ & $318(100.0)$ \\
\hline
\end{tabular}

tients. Responses suggested a major defect in the knowledge about well-established risk factors of OC among Iraqi individuals. The only significant difference in correct answers was observed in patients receiving information from a dentist, which signifies the role of a dentist in improving the public awareness and knowledge about OC. An advise provided by the dentist about risk factors and early detection is of paramount importance in prevention and successful treatment of OC $[29,30]$.

Globally, public awareness about OC was reported to be low, with significant lack of knowledge about signs and symptoms. The limitation of the current study was mainly lack of similar studies about Iraqi population, from which comparison could be withdrawn. In addition, this type of surveys cannot provide sufficient amount of details due to restricted nature of the answers, which limits the respondents to fully express their knowledge about investigated topic. Current results must be interpreted with a caution, as the questionnaire was distributed to patients attending selected GSD in Baghdad, which may restrict the representative potential of Iraqi community. However, this pilot study provides basis for future surveys involving larger sample at different cities in Iraq to highlight the actual knowledge of Iraqi population towards OC. Despite these limitations, findings of this study were not deviated from previous researches, in which Iraqi population showed low-level of awareness about OC that require community-based educational programs emphasizing the importance of early detection and management of OC. In addition, the knowledge acquired from dentists is pivotal in enhancing individuals' awareness about OC. 


\section{CONFLICT OF INTERESTS}

The authors declare no potential conflicts of interest with respect to the research, authorship, and/or publication of this article.

\section{References}

1. Rikardsen OG, Bjerkli IH, Uhlin-Hansen L, Hadler-Olsen E, Steigen SE. Clinicopathological characteristics of oral squamous cell carcinoma in Northern Norway: a retrospective study. BMC Oral Health 2014; 14: 103.

2. Jemal A, Bray F, Center MM, Ferlay J, Ward E, Forman D. Global cancer statistics. CA Cancer J Clin 2011; 61: 69-90.

3. Llewellyn CD, Johnson NW, Warnakulasuriya KA. Risk factors for squamous cell carcinoma of the oral cavity in young people a comprehensive literature review. Oral Oncol 2001; 37: 401-418.

4. Drummond SN, Gomez RS, Motta Noronha JC, Pordeus IA, Barbosa AA, De Marco L. Association between GSTT-1 gene deletion and the susceptibility to oral squamous cell carcinoma in cigarette-smoking subjects. Oral Oncol 2005; 41: 515-519.

5. Museedi OS, Younis WH. Oral cancer trends in Iraq from 2000 to 2008. The Saudi Journal for Dental Research 2014; 5: 41-47.

6. Znaor A, Brennan P, Gajalakshmi V, et al. Independent and combined effects of tobacco smoking, chewing and alcohol drinking on the risk of oral, pharyngeal and esophageal cancers in Indian men. Int J Cancer 2003; 105: 681-686.

7. Han S, Chen Y, Ge X, et al. Epidemiology and cost analysis for patients with oral cancer in a university hospital in China. BMC Public Health 2010; 10: 196.

8. Shugars DC, Patton LL. Detecting, diagnosing, and preventing oral cancer. Nurse Pract 1997; 22: 105, 109-110, 113-105 passim.

9. Feller L, Lemmer J. Oral squamous cell carcinoma: epidemiology, clinical presentation and treatment. J Cancer Ther 2012; 3: 263.

10. Devadiga A, Prasad KV. Knowledge about oral cancer in adults attending a Dental Hospital in India. Asian Pac J Cancer Prev 2010; 11: 1609-1613.

11. O'Connor TE, Papanikolaou V, Keogh IJ. Public knowledge of head and neck cancer. Ir Med J 2010; 103: 105-107.

12. West R, Alkhatib M, McNeill A, Bedi R. Awareness of mouth cancer in Great Britain. Br Dental J 2006; 200: 167.

13. Ghani WM, Doss JG, Jamaluddin M, Kamaruzaman D, Zain RB. Oral cancer awareness and its determinants among a selected $\mathrm{Ma}$ laysian population. Asian Pac J Cancer Prev 2013; 14: 1957-1963.

14. Al-Maweri SA, Addas A, Tarakji B, et al. Public awareness and knowledge of oral cancer in Yemen. Asian Pac J Cancer Prev 2014; 15: 10861-10865.

15. Hussein AA, Helder MN, de Visscher JG, et al. Global incidence of oral and oropharynx cancer in patients younger than 45 years versus older patients: a systematic review. Eur J Cancer 2017; 82: 115-127.

16. Canto MT, Devesa SS. Oral cavity and pharynx cancer incidence rates in the United States, 1975-1998. Oral Oncol 2002; 38: 610-617.

17. Alkhuzai AH, Ahmad IJ, Hweel MJ, et al. Violence-related mortality in Iraq from 2002 to 2006. N Engl J Med 2008; 358: 484-493.

18. Shenoi R, Devrukhkar V, Sharma BK, Sapre SB, Chikhale A. Demographic and clinical profile of oral squamous cell carcinoma patients: a retrospective study. Indian J Cancer 2012; 49: 21-26.

19. Shuman AG, Entezami P, Chernin AS, Wallace NE, Taylor JM, Hogikyan ND. Demographics and efficacy of head and neck cancer screening. Otolaryngol Head Neck Surg 2010; 143: 353-360.

20. Singh K, Sharma D, Kaur M, Gauba K, Thakur JS, Kumar R. Effect of health education on awareness about oral cancer and oral self-examination. J Educ Health Promot 2017; 6: 27.

21. Petti S. Lifestyle risk factors for oral cancer. Oral Oncol 2009; 45: 340-350.

22. Meurman JH. Infectious and dietary risk factors of oral cancer. Oral Oncol 2010; 46: 411-413.
23. Woods GM, Howson LJ, Brown GK, et al. Immunology of a transmissible cancer spreading among Tasmanian devils. J Immunol 2015; 195: 23-29.

24. Amarasinghe HK, Usgodaarachchi US, Johnson NW, Lalloo R, Warnakulasuriya S. Public awareness of oral cancer, of oral potentially malignant disorders and of their risk factors in some rural populations in Sri Lanka. Community Dent Oral Epidemiol 2010; 38: $540-548$.

25. Al-Rawi N, Kawas S, Imad O. Public awareness and attitude toward oral cancer screening in United Arab Emirates. J Int Dental Med Res 2012; 5: 149-153.

26. Wimardhani YS, Warnakulasuriya S, Subita GP, Soegyanto AI, Pradono SA, Patoni N. Public awareness of oral cancer among adults in Jakarta, Indonesia. J Investig Clin Dent 2019; 10: e12379.

27. Formosa J, Jenner R, Nguyen-Thi MD, Stephens C, Wilson C, Ariyawardana A. Awareness and knowledge of oral cancer and potentially malignant oral disorders among dental patients in far North Queensland, Australia. Asian Pac J Cancer Prev 2015; 16 4429-4434.

28. Al-Jaber A, Al-Nasser L, El-Metwally A. Epidemiology of oral cancer in Arab countries. Saudi Med J 2016; 37: 249-255.

29. Saleh A, Kong YH, Vengu N, Badrudeen H, Zain RB, Cheong SC. Dentists' perception of the role they play in early detection of oral cancer. Asian Pac J Cancer Prev 2014; 15: 229-237.

30. Hussain QA, Awan KH. Role of dental profession in oral cancer prevention and diagnosis. J Contemp Dent Pract 2016; 17: 963-964. 